\title{
POLA KONSUMSI DAN TINGKAT KETAHANAN PANGAN RUMAH TANGGA MISKIN DI KECAMATAN GADINGREJO KABUPATEN PRINGSEWU
}

\author{
(Food Consumption Pattern and Food Security Level of Poor Households in Gadingrejo Subdistrict \\ Pringsewu Regency)
}

Yolanda Agustina, Fembriarti Erry Prasmatiwi, Rabiatul Adawiyah

Jurusan Agribisnis, Fakultas Pertanian, Universitas Lampung, J1. Prof. Dr. Soemantri Brodjonegoro No. 1

Bandar Lampung 35145, E-mail: fembriarti.erry@fp.unila.ac.id

\begin{abstract}
This research aimed to analyze the food consumption pattern, the level of food security, and factors that affected the level of food security of poor households. The location was chosen purposively at Gadingrejo Subdistrict, Pringsewu Regency in which respondents were 61 poor households. The data of this research were primary data and secondary data collected in April - Mei 2018 and analyzed using statistic descriptive analysis, cross classification between the share of food expenditure and availability in addition to food sufficiency level, and ordinal logistic regression analysis. The results of this research showed that there were 14 types of food consumed by households per day, the household PPH score of Demapan Program members was 69.78 and nonmembers was 65.62. As many as 46.67 percent member households of Demapan Program and 35.48 percent nonmember households of the Program were classified as food secured. The factors affected the level of food security were household income, the number of household members, and price of the rice. There was no difference in the level of food security between member and nonmember households of Demapan Program.
\end{abstract}

Key words: consumption pattern, demapan program, food security

\section{PENDAHULUAN}

Pangan merupakan kebutuhan yang paling mendasar bagi manusia untuk mempertahankan hidup, sehingga pemenuhan kebutuhan pangan menjadi bagian dari hak asasi manusia. Tercapainya ketahanan pangan tercermin dari ketersediaan pangan yang cukup, terdistribusi merata dan aman dikonsumsi bagi setiap warga untuk menjalankan aktivitasnya sehari-hari. Ketahanan pangan bagi suatu negara merupakan hal yang sangat penting, terutama bagi negara dengan jumlah penduduk yang sangat banyak dan terus meningkat seperti Indonesia, sehingga pemenuhan kebutuhan pangan untuk pangan pokok menjadi sebuah keharusan.

Provinsi Lampung merupakan salah satu provinsi yang memberikan kontribusi cukup besar terhadap produksi padi di Indonesia. Sumbangan produksi padi di Provinsi Lampung berasal dari produksi di tingkat kabupaten, diantaranya adalah Kabupaten Pringsewu. Kecamatan Gadingrejo merupakan penyumbang produksi padi sawah terbesar di Kabupaten Pringsewu dengan luas panen sebesar 7.922 ha dengan hasil produksi sebesar 42.866 ton (BPS Kabupaten Pringsewu 2017ª).
Menurut Ariningsih dan Rachman (2008), meskipun persediaan pangan cukup secara nasional maupun regional, tidak menjamin adanya ketahanan pangan rumah tangga atau individu. Hal tersebut dikarenakan tidak semua rumah tangga pada suatu daerah mampu mengakses pangan yang tersedia. Fenomena yang sama juga terjadi di Kecamatan Gadingrejo, meskipun daerah tersebut merupakan sentra penghasil pangan pokok yaitu padi sawah tertinggi di Kabupaten Pringsewu, namun dihadapkan juga dengan permasalahan tingkat kemiskinan yang tinggi.

Menurut Dinas Ketahanan Pangan Kabupaten Pringsewu (2017), konsumsi pangan masyarakat Kabupaten Pringsewu dinilai belum ideal. Ratarata tingkat konsumsi energi masyarakat Kabupaten Pringsewu sebesar 1.826 kkal/kap/hari dan konsumsi protein sebesar 46,92 gram/kap/hari. Angka tersebut masih berada di bawah standar Angka Kecukupan Gizi (AKG) ideal menurut WKNPG X tahun 2012. Berdasarkan aspek kualitas, konsumsi pangan rumah tangga dapat dievaluasi dengan pendekatan skor Pola Pangan Harapan (PPH). Angka skor PPH Kabupaten Pringsewu tahun 2017 sebesar 86,10 dan angka tersebut masih berada di bawah skor PPH ideal yaitu 100. Hal ini mengindikasikan bahwa kualitas 
konsumsi pangan masyarakat Kabupaten Pringsewu dinilai belum baik.

Masalah kemiskinan dan masalah gizi merupakan masalah yang bersifat kompleks. Tingginya angka persentase rumah tangga yang belum sejahtera, tingkat konsumsi dan skor PPH yang belum ideal akan memungkinkan terjadinya masalah rawan pangan yang dapat mengancam ketahanan pangan pada rumah tangga. Kecamatan Gadingrejo merupakan kecamatan yang memiliki jumlah keluarga pra sejahtera terbanyak dibandingkan kecamatan lainnya di Kabupaten Pringsewu. Jumlah keluarga pra sejahtera di Kecamatan Gadingrejo tahun 2016 adalah sebanyak 3.114 KK (19,04\%) (BPS Kabupaten Pringsewu 2017b).

Program Desa Mandiri Pangan (Demapan) merupakan salah satu upaya pemerintah untuk menanggulangi kemiskinan dan sekaligus mengatasi kerawanan pangan di pedesaan. Program Demapan di bawah binaan Dinas Ketahanan Pangan Kabupaten Pringsewu dilaksanakan di tujuh desa yang berada di empat kecamatan. Kecamatan Gadingrejo dipilih karena merupakan daerah penghasil produksi pangan pokok tertinggi yaitu padi sawah, namun dihadapi dengan permasalahan kemiskinan yaitu memiliki jumlah keluarga pra sejahtera terbanyak di Kabupaten Pringsewu. Oleh sebab itu, penelitian ini bertujuan untuk mengetahui pola konsumsi pangan, tingkat ketahanan pangan, dan faktorfaktor yang mempengaruhi tingkat ketahanan pangan rumah tangga miskin anggota dan nonanggota Program Demapan di Kecamatan Gadingrejo Kabupaten Pringsewu.

\section{METODE PENELITIAN}

Penelitian ini dilakukan dengan menggunakan metode survei. Lokasi penelitian dipilih secara sengaja (purposive), yaitu di Pekon Klaten, Kecamatan Gadingrejo, Kabupaten Pringsewu dengan pertimbangan bahwa lokasi tersebut merupakan satu-satunya desa yang mendapatkan bantuan Program Demapan di Kecamatan Gadingrejo.

Penentuan jumlah sampel dalam penelitian ini merujuk pada teori Arikunto (2006), dimana jika populasi penelitian berjumlah kurang dari 100 maka sampel yang diambil adalah seluruhnya, namun jika populasi penelitian berjumlah lebih dari 100, maka sampel dapat diambil antara 10-15 persen atau 20-25 persen atau lebih.
Populasi dalam penelitian ini adalah rumah tangga miskin yang berjumlah $61 \mathrm{KK}$ dan diambil seluruhnya, terbagi menjadi $30 \mathrm{KK}$ rumah tangga miskin anggota Program Demapan dan $31 \mathrm{KK}$ rumah tangga miskin nonanggota Program Demapan. Unit analisis penelitian ini adalah rumah tangga dengan responden yaitu ibu rumah tangga dan kepala rumah tangga. Waktu pengambilan data dilakukan pada bulan April hingga Mei 2018.

Metode analisis data yang digunakan pada penelitian ini adalah metode analisis statistik deskriptif dan analisis statistik verifikatif dengan model ordinal logit. Analisis statistik deskriptif digunakan untuk mengetahui pola konsumsi dan tingkat ketahanan pangan rumah tangga. Analisis statistik dengan model ordinal logit digunakan untuk mengetahui faktor-faktor yang mempengaruhi tingkat ketahanan pangan rumah tangga miskin anggota dan nonanggota Program Demapan.

Jumlah konsumsi pangan rumah tangga diperoleh dengan menggunakan metode recall konsumsi pangan 24 jam yang lalu, selama dua hari tidak berturut-turut. Hasil recall dikonversi ke dalam zat gizi energy, kemudian dirata-ratakan dalam satu hari. Perhitungan kandungan zat gizi bahan makanan dan Angka Kecukupan Gizi (AKG) yang dianjurkan dihitung dengan rumus sebagai berikut (Hardinsyah dan Martianto 1989):

$\mathrm{KG}_{\mathrm{ij}}=\left(\frac{B \mathrm{j}}{100} \times \mathrm{G}_{\mathrm{ij}} \times \frac{\mathrm{BDDj}}{100}\right)$

Keterangan:

$\mathrm{KG}_{\mathrm{ij}}$ = Kandungan zat gizi (energi) jenis pangan yang dikonsumsi

$\mathrm{B}_{\mathrm{j}} \quad=$ Berat jenis pangan yang dikonsumsi (gram)

$\mathrm{G}_{\mathrm{ij}} \quad=$ Kandungan zat gizi (i) yang dikonsumsi dari pangan (j) dalam 100 gram jenis pangan

$\mathrm{BDD}_{\mathrm{j}}=$ Bagian yang dapat dimakan (dalam \%/ gram dari $100 \%$ pangan $\mathrm{j}$ )

$\mathrm{AKG}=\frac{\mathrm{BB}}{\mathrm{BB} \text { standar }} \times \mathrm{AKG}$ standar.

Keterangan:

AKG = Angka kecukupan gizi (energi dan protein)

$\mathrm{BB}=$ Berat badan aktual $(\mathrm{kg})$

$\mathrm{BB}$ standar = Berat badan standar $(\mathrm{kg})$

AKG standar = Angka kecukupan zat gizi anjuran WKNPG X tahun 2012 
Tingkat Kecukupan Energi (TKE) dihitung dengan rumus sebagai berikut:

$\mathrm{TKE}(\% \mathrm{AKE})=\frac{\sum \text { Konsumsi energi }}{\text { AKE yang dianjurkan }} \times 100 \% \ldots \ldots$

Keterangan:

TKE = Tingkat kecukupan energi

$\sum$ Konsumsi energi $=$ Jumlah asupan energi (kkal/hari)

AKE anjuran = Angka kecukupan energi yang dianjurkan (kkal/hari)

Skor PPH aktual rumah tangga dihitung dengan menggunakan rumus sebagai berikut:

Skor PPH masing-masing golongan pangan $=\left(\frac{\mathrm{A}}{\mathrm{B}} \times 100 \%\right) \times \mathrm{C}$.

\section{Skor PPH}

$=\sum$ Skor PPH sembilan golongan pangan...

Keterangan:

$\mathrm{A}=$ Konsumsi energi per golongan pangan (kkal/hari)

$\mathrm{B}=\mathrm{AKE}(\mathrm{kkal} / \mathrm{hari})$

$\mathrm{C}=$ Nilai bobot masing-masing golongan pangan

Tingkat ketahanan pangan rumah tangga diukur menggunakan pengukuran derajat ketahanan pangan rumah tangga yaitu klasifikasi silang indikator antara pangsa pengeluaran pangan dan konsumsi energi yang dapat dilihat pada Tabel 1 .

Pangsa pengeluaran pangan dihitung dengan rumus sebagai berikut:

$\mathrm{PPP}=\frac{\mathrm{PP}}{\mathrm{TP}} \times 100 \%$

Keterangan:

$\mathrm{PPP}=$ Pangsa pengeluaran pangan $(\%)$

$\mathrm{PP}=$ Pengeluaran untuk belanja pangan $(\mathrm{Rp} / \mathrm{bln})$

$\mathrm{TP}=$ Total pengeluaran rumah tangga $(\mathrm{Rp} / \mathrm{bln})$

Tabel 1. Kriteria tingkat ketahanan pangan rumah tangga

\begin{tabular}{lcc}
\hline \multirow{2}{*}{ Konsumsi energi } & \multicolumn{2}{c}{ Pangsa pengeluaran pangan } \\
\cline { 2 - 3 } & $\begin{array}{l}\text { Rendah } \\
(<60 \%)\end{array}$ & $\begin{array}{l}\text { Tinggi } \\
(\geq 60 \%)\end{array}$ \\
\hline Cukup $(>80 \%)$ & $\begin{array}{l}\text { Tahan } \\
\text { pangan }\end{array}$ & $\begin{array}{l}\text { Rentan } \\
\text { pangan }\end{array}$ \\
\hline Kurang $(\leq 80 \%)$ & $\begin{array}{l}\text { Kurang } \\
\text { pangan }\end{array}$ & $\begin{array}{l}\text { Rawan } \\
\text { pangan }\end{array}$ \\
\hline
\end{tabular}

Sumber: Maxwell et al. (2000) dalam Indriani (2015)
Faktor-faktor yang mempengaruhi tingkat ketahanan pangan rumah tangga dijawab dengan analisis statistik verifikatif menggunakan model ordinal logit dengan persamaan sebagai berikut:

$$
\begin{aligned}
\mathrm{Li}= & \ln \left[\frac{\mathrm{Pi}}{1-\mathrm{Pi}}\right]=\mathrm{Zi}=\alpha+\beta_{1} \mathrm{X}_{1}+\beta_{2} \mathrm{X}_{2}+\beta_{3} \mathrm{X}_{3}+ \\
& \beta_{4} \mathrm{X}_{4}+\beta_{5} \mathrm{X}_{5}+\beta_{6} \mathrm{D}+\mathrm{e} \ldots \ldots \ldots \ldots \ldots \ldots \ldots \ldots \ldots \ldots \ldots \ldots \ldots \ldots
\end{aligned}
$$

Keterangan:

$\mathrm{Pi}=$ Probabilitas rumah tangga untuk mencapai tahan pangan, dimana probabilitas $\mathrm{P} 1=$ $\mathrm{P}(\mathrm{Y}=4)$ untuk rumah tangga tahan pangan, probabilitas $\mathrm{P} 2=\mathrm{P}(\mathrm{Y}=3)$ untuk rumah tangga kurang pangan, probabilitas $\mathrm{P} 3=$ $\mathrm{P}(\mathrm{Y}=2)$ untuk rumah tangga rentan pangan, dan probabilitas $\mathrm{P} 4=\mathrm{P}(\mathrm{Y}=1)$ untuk rumah tangga rawan pangan

$\mathrm{Li}=$ Tingkat ketahanan pangan rumah tangga

$\alpha=$ Intersep

$\beta \mathrm{i}=$ Koefisien regresi parameter $(\mathrm{i}=1,2,3,4,5,6)$

$\mathrm{X}_{1}=$ Pendapatan rumah tangga (Rp/bulan)

$\mathrm{X}_{2}=$ Pendidikan ibu rumah tangga (tahun)

$\mathrm{X}_{3}=$ Jumlah anggota rumah tangga (orang)

$\mathrm{X}_{4}=$ Harga beras $(\mathrm{Rp} / \mathrm{kg})$

$\mathrm{X}_{5}=$ Harga gula $(\mathrm{Rp} / \mathrm{kg})$

$\mathrm{D}=$ Dummy keikutsertaan Program Demapan nilai $1=$ anggota ; nilai $0=$ nonanggota

$\mathrm{e}=$ Error term

Pengujian hipotesis menggunakan Maximum Likelihood Estimation (MLE) untuk menghitung nilai Likelihood Ratio Index (LRI), uji Likelihood Ratio (LR) dan uji Wald. Uji Likelihood Ratio Index (LRI) digunakan untuk mengetahui ketepatan model yang dinyatakan dengan berapa persen variabel dependen dijelaskan oleh variabel independen yang dimasukkan ke dalam model regresi. Uji Likelihood Ratio (LR) digunakan untuk mengetahui pengaruh semua varibel independen secara bersama-sama terhadap variabel dependen. Uji Wald digunakan untuk menguji pengaruh masing-masing variabel independen terhadap variabel dependen melalui perubahan odd.

\section{HASIL DAN PEMBAHASAN}

\section{Karakteristik Responden}

Kelompok usia responden ibu rumah tangga dan kepala rumah tangga baik anggota maupun nonanggota Program Demapan berada pada kisaran 37-57 tahun, termasuk dalam usia produktif. Tingkat pendidikan yang ditempuh oleh ibu rumah tangga dan kepala rumah tangga 
anggota dan nonanggota Program Demapan dengan tahun sukses antara 0-6 tahun (SD). Ratarata jumlah anggota rumah tangga responden sebanyak 4 orang yaitu 50,00 persen pada rumah tangga anggota Program Demapan dan 64,52 persen pada rumah tangga nonanggota Program Demapan. Sebesar 40,00 persen ibu rumah tangga anggota dan 48,39 persen ibu rumah tangga nonanggota Program Demapan bekerja sebagai ibu rumah tangga. Sebesar 46,67 persen kepala rumah tangga anggota dan 48,39 persen kepala rumah tangga nonanggota Program Demapan berprofesi sebagai buruh tani. Pendapatan rata-rata rumah tangga anggota Program Demapan sebesar Rp2.235.736,11 per bulan, sedangkan rumah tangga nonanggota Program Demapan sebesar Rp2.084.247,31 per bulan. Sumber pendapatan terbesar semua rumah tangga berasal dari pendapatan nonfarm dengan kontribusi lebih dari 50 persen dari total pendapatan rumah tangga.

\section{Pelaksanaan Program Demapan}

Desa Mandiri Pangan adalah desa yang masyarakatnya mempunyai kemampuan untuk mewujudkan ketahanan pangan dan gizi melalui pengembangan subsistem ketersediaan, subsistem distribusi, dan subsistem konsumsi dengan memanfaatkan sumberdaya setempat secara berkelanjutan. Program Demapan di lokasi penelitian tidak bekerja atau bersinergi pada ketiga subsistem tersebut. Kegiatan ekonomi produktif yang dilakukan hanya berupa pemeliharaan kambing saja. Kegiatan lainnya yaitu rapat atau pertemuan rutin yang dilakukan tiga bulan sekali untuk membahas kendala yang terjadi dalam pemeliharaan kambing. Secara keseluruhan, pelaksanaan Program Demapan di Pekon Klaten dari penyaluran bantuan hingga pemeliharaan kambing sudah berjalan dengan baik serta tidak ada kendala atau masalah yang terjadi, hanya saja sasaran kegiatan Program Demapan kurang sesuai dengan pedoman teknis. Sasaran kegiatan Program Demapan seharusnya diberikan kepada rumah tangga miskin, namun pada kenyataannya terdapat beberapa rumah tangga anggota Program Demapan yang dipilih secara subjektif bukan berdasarkan latar belakang ekonomi yang dimiliki rumah tangga.

\section{Pola Konsumsi Pangan Rumah Tangga}

Pola konsumsi pangan rumah tangga dilihat berdasarkan jenis, jumlah, frekuensi pangan yang dikonsumsi, serta skor PPH rumah tangga. Berdasarkan hasil penelitian, rata-rata jumlah jenis pangan yang dikonsumsi rumah tangga anggota dan nonanggota Program Demapan terdiri dari 14 jenis per hari. Semakin banyak dan beragam jumlah jenis pangan yang dikonsumsi oleh rumah tangga per hari, maka akan semakin terpenuhi zat gizi yang dibutuhkan rumah tangga (Kementerian Kesehatan RI 2014).

Jumlah konsumsi pangan rumah tangga dapat dilihat dari rata-rata konsumsi energi per rumah tangga per hari. Pada Tabel 2 dapat dilihat bahwa rata-rata konsumsi energi aktual rumah tangga anggota Program Demapan adalah 7.120,56 kkal/ rumah tangga/hari dengan AKE sebesar 8.215,16 kkal/rumah tangga/hari, sedangkan rata-rata konsumsi energi aktual rumah tangga nonanggota Program Demapan adalah 6.639,71 kkal/rumah tangga/hari dengan AKE sebesar 8.009,02 kkal/ rumah tangga/hari. Konsumsi energi terbesar rumah tangga di lokasi penelitian disumbang oleh golongan pangan padi-padian. Persentase TKE rumah tangga diperoleh dari rata-rata konsumsi energi aktual dibagi dengan total AKE yang dianjurkan bagi rumah tangga. Nilai TKE rumah tangga anggota dan nonanggota Program Demapan berada pada kategori cukup (Indriani 2015).

Frekuensi konsumsi berbagai jenis pangan diklasifikasikan menjadi kategori sangat sering (>1x/hari atau tiap kali makan), sering (1x/hari, 4$6 \mathrm{x} /$ minggu), cukup sering ( $\mathrm{x} / \mathrm{ming}$ gu), cukup $(<3 \mathrm{x} /$ minggu, $1-2 \mathrm{x} /$ minggu $)$, jarang $(<1 \mathrm{x} /$ minggu, 1x/bulan), dan tidak pernah (Suhardjo 1989) lalu dihitung dalam skor.

Tabel 2. Jumlah konsumsi energi rumah tangga di Kecamatan Gadingrejo

\begin{tabular}{lrc}
\hline \multirow{2}{*}{ Golongan Pangan } & \multicolumn{2}{c}{$\begin{array}{c}\text { Konsumsi Energi Rumah Tangga } \\
\text { (kkal/hari) }\end{array}$} \\
\cline { 2 - 3 } & $\begin{array}{c}\text { Anggota Program } \\
\text { Demapan }\end{array}$ & $\begin{array}{c}\text { Nonanggota } \\
\text { Program Demapan }\end{array}$ \\
\hline Padi-padian & $4.428,64$ & $4.159,60$ \\
Umbi-umbian & 88,66 & 80,36 \\
Hewani & 490,45 & 412,04 \\
Minyak dan lemak & $1.095,66$ & $1.039,61$ \\
Buah dan biji & 115,90 & 153,45 \\
berminyak & 321,51 & 343,74 \\
Kacang-kacangan & 141,39 & 150,32 \\
Gula & 294,14 & 229,88 \\
Sayur dan buah & 144,21 & 70,69 \\
Lain-lain & $7.120,56$ & $6.639,71$ \\
Total & $8.215,16$ & $8.009,02$ \\
AKE & 86,68 & 82,90 \\
\hline TKE (\%) & &
\end{tabular}


Skor tertinggi dari jenis pangan sumber karbohidrat adalah beras/nasi dengan skor sebesar 50,00. Hal ini dikarenakan beras merupakan pangan pokok sebagai sumber energi utama yang dikonsumsi rumah tangga setiap hari. Jenis pangan sumber protein hewani yang paling sering dikonsumsi oleh rumah tangga baik anggota maupun nonanggota Program Demapan adalah telur dengan skor tertinggi sebesar 6,17 pada rumah tangga anggota Program Demapan dan skor sebesar 7,32 pada rumah tangga nonanggota Program Demapan. Ikan asin dan kerupuk ikan merupakan sumber protein hewani kedua yang juga banyak dikonsumsi oleh sebagian besar rumah tangga. Tempe merupakan jenis pangan nabati olahan kacang-kacangan yang sangat digemari rumah tangga anggota $(13,90)$ dan nonanggota Program Demapan $(11,87)$ dibandingkan jenis lauk pauk nabati lainnya dengan frekuensi konsumsi cukup sering. Buah pisang memiliki skor tertinggi dari frekuensi konsumsi jenis pangan golongan buah-buahan. Buah pisang paling sering dikonsumsi oleh rumah tangga di lokasi penelitian dibandingkan jenis, karena kemudahan dalam memperolehnya.

Mutu atau kualitas konsumsi pangan rumah tangga dapat dilihat dari pendekatan Pola Pangan Harapan (PPH) yang dikenal sebagai skor PPH. Berdasarkan hasil penelitian, skor $\mathrm{PPH}$ rumah tangga anggota Program Demapan lebih tinggi dibandingkan dengan skor PPH rumah tangga nonanggota Program Demapan. Skor PPH rumah tangga anggota Program Demapan sebesar 69,78 sedangkan skor PPH rumah tangga nonanggota Program Demapan sebesar 65,62. Skor PPH rumah tangga dalam penelitian ini lebih rendah dibandingkan skor PPH hasil penelitian Indiako, Ismono, dan Soelaiman (2014) yang menunjukkan bahwa skor PPH rumah tangga pelaksana dan nonpelaksana Program Model Pengembangan Pangan Pokok Lokal (MP3L) berada di atas angka 80. Hal tersebut dikarenakan adanya penganekaragaman jenis pangan yang dikonsumsi oleh rumah tangga pada penelitian tersebut yaitu dengan cara pensubstitusian beras dengan tiwul, sehingga nilai skor PPH yang diperoleh lebih tinggi. Skor PPH rumah tangga anggota dan nonanggota Program Demapan masih berada di bawah ketetapan capaian skor PPH sebesar 100 . Terdapat dua golongan pangan yang memiliki skor PPH melebihi ketetapan yaitu golongan padipadian dan golongan minyak dan lemak. Golongan pangan yang memiliki selisih minus antara capaian skor PPH aktual dengan ketetapan yaitu golongan umbi-umbian, pangan hewani, buah dan biji berminyak, kacang-kacangan, gula, serta sayur dan buah. Hal tersebut menunjukkan bahwa konsumsi pangan rumah tangga anggota dan nonanggota Program Demapan kurang beragam serta kualitas konsumsi pangan rumah tangga masih rendah.

\section{Tingkat Ketahanan Pangan Rumah Tangga}

\section{Pangsa Pengeluaran Pangan dan Tingkat Kecukupan Energi (TKE)}

Pengeluaran rumah tangga terdiri dari pengeluaran pangan dan pengeluaran nonpangan. Rata-rata pengeluaran pangan rumah tangga anggota Program Demapan dalam satu bulan adalah sebesar Rp1.215.766,67 (54,57\%) dari total pengeluaran rumah tangga, sedangkan rata-rata pengeluaran pangan rumah tangga nonanggota Program Demapan dalam satu bulan adalah sebesar Rp1.158.613,71 $(55,61 \%)$ dari total pengeluaran rumah tangga. Untuk rata-rata pengeluaran nonpangan rumah tangga anggota dan nonanggota Program Demapan dalam satu bulan masingmasing adalah sebesar 45,43 persen dan 44,39 persen dari total pengeluaran rumah tangga. Hal tersebut menunjukkan bahwa masing-masing rumah tangga memiliki proporsi pengeluaran pangan kurang dari 60 persen dari total pengeluaran rumah tangga. Semakin kecil persentase pengeluaran pangan terhadap total pengeluaran rumah tangga maka semakin sejahtera rumah tangga tersebut (Ilham dan Sinaga 2007).

Pada Tabel 3 dapat dilihat bahwa pengeluaran pangan terbesar adalah untuk pangan pokok dan lauk pauk. Rumah tangga anggota Program Demapan membelanjakan uangnya untuk pangan pokok dengan persentase sebesar 15,32 persen dan lauk pauk sebesar 14,53 persen, sedangkan persentase pengeluaran rumah tangga nonanggota Program Demapan untuk pangan pokok sebesar 15,30 persen dan lauk pauk sebesar 14,42 persen dari total pengeluaran rumah tangga.

Pengeluaran nonpangan terbesar adalah untuk rokok. Pengeluaran untuk rokok mengambil proporsi yang cukup tinggi dalam pengeluaran nonpangan yaitu lebih dari 10 persen pada masingmasing kategori rumah tangga, bahkan lebih tinggi jika dibandingkan dengan pengeluaran pangan untuk sayuran dan buah-buahan 
Tabel 3. Rata-rata total pengeluaran rumah tangga di Kecamatan Gadingrejo dalam satu bulan

\begin{tabular}{|c|c|c|c|c|}
\hline \multirow[b]{2}{*}{ Jenis pengeluaran } & \multicolumn{2}{|c|}{ Anggota Program Demapan } & \multicolumn{2}{|c|}{ Nonanggota Program Demapan } \\
\hline & $\begin{array}{l}\text { Rata-rata pengeluaran } \\
\text { (Rp/bulan) }\end{array}$ & $(\%)$ & $\begin{array}{l}\text { Rata-rata pengeluaran } \\
\text { (Rp/bulan) }\end{array}$ & $(\%)$ \\
\hline \multicolumn{5}{|l|}{ Pangan: } \\
\hline \multicolumn{5}{|l|}{ Pangan pokok: } \\
\hline Beras & $272.583,33$ & 12,23 & $255.483,87$ & 12,26 \\
\hline Nonberas & $68.791,67$ & 3,09 & $63.229,84$ & 3,04 \\
\hline Lauk pauk & $323.627,78$ & 14,53 & $300.491,94$ & 14,42 \\
\hline Kacang-kacangan & $21.388,89$ & 0,96 & $17.311,83$ & 0,83 \\
\hline Sayuran & $147.283,33$ & 6,61 & $152.225,81$ & 7,31 \\
\hline Buah-buahan & $36.333,33$ & 1,63 & $37.344,09$ & 1,79 \\
\hline Lemak & $55.977,78$ & 2,51 & $44.787,63$ & 2,15 \\
\hline Makanan jajanan & $64.783,33$ & 2,91 & $67.674,19$ & 3,25 \\
\hline Minuman & $102.330,56$ & 4,59 & $100.241,94$ & 4,81 \\
\hline Bumbu-bumbu & $122.666,67$ & 5,51 & $119.822,58$ & 5,75 \\
\hline Total pengeluaran pangan & $1.215 .766,67$ & 54,57 & $1.158 .613,71$ & 55,61 \\
\hline \multicolumn{5}{|l|}{ Nonpangan: } \\
\hline Listrik & $54.333,33$ & 2,44 & $52.354,84$ & 2,51 \\
\hline Gas & $52.000,00$ & 2,33 & $47.935,48$ & 2,30 \\
\hline Bahan bakar & $87.233,33$ & 3,92 & $70.451,61$ & 3,38 \\
\hline Biaya sekolah & $62.250,00$ & 2,79 & $52.069,89$ & 2,50 \\
\hline Uang saku & $237.444,44$ & 10,66 & $200.344,09$ & 9,62 \\
\hline Pakaian & $46.986,11$ & 2,11 & $33.965,05$ & 1,63 \\
\hline Kesehatan & $18.166,67$ & 0,82 & $20.225,81$ & 0,97 \\
\hline Arisan & $16.666,67$ & 0,75 & $12.258,06$ & 0,59 \\
\hline Rekreasi & $1.527,78$ & 0,07 & 940,86 & 0,05 \\
\hline Transportasi & $25.500,00$ & 1,14 & $26.451,61$ & 1,27 \\
\hline Komunikasi & $47.400,00$ & 2,13 & $43.064,52$ & 2,07 \\
\hline Sewa/perbaikan rumah & $3.263,89$ & 0,15 & $2.674,73$ & 0,13 \\
\hline Sabun & $69.088,89$ & 3,10 & $68.916,67$ & 3,31 \\
\hline Kecantikan & $16.166,67$ & 0,73 & $19.193,55$ & 0,92 \\
\hline Sumbangan & $17.000,00$ & 0,76 & $14.354,84$ & 0,69 \\
\hline Mengirimi anak/saudara & $26.666,67$ & 1,20 & $22.580,65$ & 1,08 \\
\hline Rokok & $230.566,67$ & 10,35 & $236.935,48$ & 11,37 \\
\hline Total pengeluaran nonpangan & $1.012 .261,11$ & 45,43 & $924.717,74$ & 44,39 \\
\hline Total pengeluaran rumah tangga & $2.228 .027,78$ & 100,00 & $2.083 .331,45$ & 100,00 \\
\hline
\end{tabular}

Sejalan dengan penelitian Hernanda, Indriani, dan Kalsum (2017) yang menunjukkan bahwa besarnya pengeluaran untuk rokok melebihi pengeluaran untuk sayuran, daging, telur, susu, atau pangan bergizi lainnya. Setelah diperoleh total pengeluaran rumah tangga yang dibagi menjadi pengeluaran pangan dan nonpangan, maka dapat dihitung pangsa pengeluaran pangan rumah tangga.

Hasil penelitian menunjukkan bahwa sebesar 56,67 persen rumah tangga anggota dan 54,84 persen rumah tangga nonanggota Program Demapan memiliki pangsa pengeluaran pangan yang berada pada kategori rendah (Tabel 4). Pangsa pengeluaran pangan rendah menunjukkan bahwa kurang dari 60 persen bagian pengeluaran rumah tangga dibelanjakan untuk pangan dan hal ini mengindikasikan bahwa rumah tangga responden tergolong dalam rumah tangga sejahtera.
Berdasarkan hasil penelitian, nilai rata-rata TKE rumah tangga anggota Program Demapan sebesar 86,68 persen dan nilai rata-rata TKE rumah tangga nonanggota Program Demapan sebesar 82,90 persen. Tingkat Kecukupan Energi (TKE) dibagi menjadi dua kriteria yaitu cukup $(>80 \%)$ dan kurang $(\leq 80 \%)$. Rumah tangga responden memiliki nilai TKE yang berada dalam kategori cukup, sebanyak 25 RT (83,33\%) pada rumah tangga anggota Program Demapan dan sebanyak 21 RT $(67,74 \%)$ pada rumah tangga nonanggota Program Demapan. Nilai TKE rumah tangga anggota Program Demapan relatif lebih besar dibandingkan dengan nilai TKE rumah tangga nonanggota Program Demapan yang berarti bahwa rumah tangga anggota Program Demapan lebih mampu menyediakan pangan yang baik dari segi kuantitas maupun kualitasnya dibandingkan dengan rumah tangga nonanggota Program Demapan 
Tabel 4. Sebaran rumah tangga berdasarkan pangsa pengeluaran pangan dan tingkat kecukupan energi di Kecamatan Gadingrejo

\begin{tabular}{|c|c|c|c|c|}
\hline \multirow[t]{2}{*}{ PPP dan TKE } & \multicolumn{2}{|c|}{$\begin{array}{l}\text { Anggota } \\
\text { Program } \\
\text { Demapan }\end{array}$} & \multicolumn{2}{|c|}{$\begin{array}{l}\text { Nonanggota } \\
\text { Program } \\
\text { Demapan }\end{array}$} \\
\hline & $\begin{array}{l}\mathrm{Jml} \\
\mathrm{RT}\end{array}$ & $(\%)$ & $\begin{array}{l}\mathrm{Jml} \\
\mathrm{RT}\end{array}$ & $(\%)$ \\
\hline PPP<60\% (rendah) & 17 & 56,67 & 17 & 54,84 \\
\hline$P P P \geq 60 \%$ (tinggi) & 13 & 43,33 & 14 & 45,16 \\
\hline Total & 30 & 100,00 & 31 & 100,00 \\
\hline TKE>80\% (cukup) & 25 & 83,33 & 21 & 67,74 \\
\hline TKE $\leq 80 \%$ (kurang) & 5 & 16,67 & 10 & 32,26 \\
\hline Total & 30 & 100,00 & 31 & 100,00 \\
\hline
\end{tabular}

.Tingkat Ketahanan Pangan

Berdasarkan hasil klasifikasi silang diketahui bahwa sebanyak 46,67 persen rumah tangga anggota dan 35,48 persen rumah tangga nonanggota Program Demapan tergolong dalam kategori tahan pangan (Tabel 5).

Rumah tangga tahan pangan menunjukkan bahwa tingkat kecukupan energi rumah tangga telah tercukupi dan memiliki pangsa pengeluaran pangan yang rendah. Hal tersebut mengindikasikan bahwa rumah tangga telah mengalokasikan pendapatannya dengan baik untuk mencukupi kebutuhan pangan terutama pangan sumber energi. Kategori tingkat ketahanan pangan terbanyak kedua adalah kelompok rentan pangan. Kategori rumah tangga kurang pangan berada pada posisi ketiga dan rawan pangan pada posisi keempat.

Tabel 5. Sebaran rumah tangga berdasarkan tingkat ketahanan pangan di Kecamatan Gadingrejo

\begin{tabular}{|c|c|c|c|c|}
\hline \multirow{2}{*}{$\begin{array}{c}\text { Tingkat } \\
\text { Ketahanan Pangan }\end{array}$} & \multicolumn{2}{|c|}{$\begin{array}{l}\text { Anggota } \\
\text { Program } \\
\text { Demapan }\end{array}$} & \multicolumn{2}{|c|}{$\begin{array}{l}\text { Nonanggota } \\
\text { Program } \\
\text { Demapan }\end{array}$} \\
\hline & $\begin{array}{l}\mathrm{Jml} \\
\mathrm{RT}\end{array}$ & $(\%)$ & $\begin{array}{l}\mathrm{Jml} \\
\mathrm{RT}\end{array}$ & $(\%)$ \\
\hline Tahan pangan & 14 & 46,67 & 11 & 35,48 \\
\hline Kurang pangan & 3 & 10,00 & 6 & 19,36 \\
\hline Rentan pangan & 11 & 36,67 & 10 & 32,26 \\
\hline Rawan pangan & 2 & 6,66 & 4 & 12,90 \\
\hline Total & 30 & 100,00 & 31 & 100,00 \\
\hline
\end{tabular}

\section{Faktor-faktor yang Mempengaruhi Tingkat Ketahanan Pangan Rumah Tangga}

Variabel dependen (Y) pada penelitian ini adalah peluang rumah tangga untuk mencapai kondisi tahan pangan. Variabel independen (X) pada penelitian ini antara lain adalah pendapatan rumah tangga $\left(\mathrm{X}_{1}\right)$, pendidikan ibu rumah tangga $\left(\mathrm{X}_{2}\right)$, jumlah anggota rumah tangga $\left(X_{3}\right)$, harga beras $\left(\mathrm{X}_{4}\right)$, harga gula $\left(\mathrm{X}_{5}\right)$, dan keikutsertaan rumah tangga dalam Program Demapan (D).

Hasil analisis regresi ordinal logit dapat dilihat pada Tabel 6. Diketahui bahwa nilai probability LR statistik sebesar 0,0072 yang berarti bahwa variabel independen $\mathrm{X}_{1}$ sampai dengan dummy secara bersama-sama berpengaruh terhadap peluang rumah tangga anggota dan nonanggota Program Demapan untuk mencapai kondisi tahan pangan.

Pendapatan rumah tangga berpengaruh positif terhadap peluang rumah tangga untuk mencapai kondisi tahan pangan. Anggraini, Zakaria, dan Prasmatiwi (2014) menyatakan bahwa peningkatan pendapatan rumah tangga menunjukkan bahwa penggunaan pendapatan tidak keseluruhan untuk pengeluaran pangan, namun dialokasikan untuk memenuhi kebutuhan nonpangan juga yang menyebabkan pangsa pengeluaran pangan menurun, sehingga derajat tahan pangan akan tercapai.

Jumlah anggota rumah tangga berpengaruh negatif terhadap peluang rumah tangga untuk mencapai kondisi tahan pangan. Besar anggota rumah tangga berpengaruh terhadap kondisi pangan dan gizi dalam rumah tangga. Selaras dengan penelitian Hernanda, Indriani, dan Listiana (2013) yang menjelaskan bahwa variabel jumlah anggota keluarga memiliki pengaruh nyata pada tingkat ketahanan pangan rumah tangga. Harga beras juga berpengaruh negatif terhadap peluang rumah tangga untuk mencapai kondisi tahan pangan. Keikutsertaan rumah tangga dalam Program Demapan tidak berpengaruh terhadap peluang rumah tangga untuk mencapai kondisi tahan pangan, sehingga tidak ada perbedaan tingkat ketahanan pangan antara rumah tangga anggota dan nonanggota Program Demapan.

\section{KESIMPULAN}

Berdasarkan hasil penelitian, dapat disimpulkan bahwa pangan yang dikonsumsi rumah tangga anggota dan nonanggota Program Demapan terdiri 
dari 14 jenis per hari dengan skor $\mathrm{PPH}$ rumah tangga anggota Program Demapan sebesar 69,78 dan rumah tangga nonanggota Program Demapan sebesar 65,62. Sebesar 46,67 persen rumah tangga anggota Program Demapan dan 35,48 persen rumah tangga nonanggota Program Demapan tergolong dalam kategori tahan pangan. Faktorfaktor yang berpengaruh terhadap tingkat ketahanan pangan rumah tangga anggota dan nonanggota Program Demapan adalah pendapatan rumah tangga, jumlah anggota rumah tangga, dan harga beras. Tidak ada perbedaan tingkat ketahanan pangan antara rumah tangga anggota dan nonanggota Program Demapan.

\section{DAFTAR PUSTAKA}

Anggraini M, Zakaria WA, dan Prasmatiwi FE. 2014. Ketahanan pangan rumah tangga petani kopi di Kabupaten Lampung Barat. JIIA, 2(2): 124-132. http://jurnal.fp.unila. ac.id/index.php/JIIA/article/download/1641/1 467. [13 November 2017].

Arikunto S. 2006. Prosedur Penelitian Suatu Pendekatan Praktek. PT. Rineka Cipta. Jakarta.

Ariningsih E dan Rachman HPS. 2008. Strategi peningkatan ketahanan pangan rumah tangga rawan pangan. Jurnal Analisis Kebijakan Pertanian, 6(3): 239-225. http://ejurnal.litbang.pertanian.go.id/index. php/akp/article/download/4314/3649. November 2017].

BPS Kabupaten Pringsewu. 2017 ${ }^{\mathrm{a}}$ Kabupaten Pringsewu dalam Angka. https://pringsewukab.bps.go.id/backend/pdf_p ublikasi/KabupatenPringsewu-Dalam-Angka2017.pdf. [1 November 2017].

BPS Kabupaten Pringsewu. 2017 ${ }^{\mathrm{b}}$. Kabupaten Pringsewu dalam Angka. Badan Pusat Statistik Kabupaten Pringsewu. Pringsewu.

Dinas Ketahanan Pangan Kabupaten Pringsewu. 2017. Laporan Skor Pola Pangan Harapan (PPH) Tahun 2017 Kabupaten Pringsewu.
Dinas Ketahanan Pangan Kabupaten Pringsewu. Pringsewu.

Hardinsyah dan Martianto D. 1989. Cara Menghitung Angka Kecukupan Energi dan Protein Serta Penilaian Mutu Gizi Konsumsi Pangan. Wirasari. Jakarta.

Hernanda E, Indriani Y, dan Kalsum U. 2017. Pendapatan dan ketahanan pangan rumah tangga petani padi di desa rawan pangan. JIIA, 5(3): 283-291. http://jurnal.fp.unila. ac.id/index.php/JIA/article/view/1641/1467.

[4 November 2017].

Hernanda T, Indriani Y, dan Listiana I. 2013. Ketahanan pangan rumah tangga petani jagung di Kecamatan Simpang Kabupaten Oku Selatan. JIIA, 1(4): 311-318. http:// jurnal.fp.unila.ac.id/index.php/JIA/article/vie w/706/648. [4 November 2017].

Ilham N dan Sinaga BM. 2007. Penggunaan pangsa pengeluaran pangan sebagai indikator komposit ketahanan pangan. Jurnal SOCA (Socio-Economic of Agriculture and Agribusiness), 7(3): 1-22. https://ojs.unud.ac.id/index.php/soca/article/vi ew/427. [16 November 2017].

Indiako, Ismono RH, dan Soelaiman A. 2014. Studi perbandingan pola alokasi lahan, pengeluaran beras dan pola konsumsi pangan antara petani ubi kayu di desa pelaksana dan nonpelaksana Program MP3L di Kabupaten Lampung Selatan. JIIA, 2 (4) : 331-336. http://jurnal. fp.unila.ac.id/ index.php/JIA/article/view/987/893. [4 November 2017].

Indriani Y. 2015. Buku Ajar: Gizi dan Pangan. CV Anugrah Utama Raharja (AURA). Bandar Lampung.

Kementerian Kesehatan RI. 2014. Pedoman Gizi Seimbang. https://www.gizi.depkes.go.id. [1 April 2019].

Suhardjo. 1989. Sosio Budaya Gizi. Departemen Pendidikan dan Kebudayaan Direktorat Jendral Pendidikan Tinggi PAU Pangan dan Gizi IPB. Bogor. 